\title{
A second IgG-binding protein in Staphylococcus aureus
}

\author{
Lihong Zhang, Karin Jacobsson, Jozsef Vasi, Martin Lindberg \\ and Lars Frykberg
}

Author for correspondence: Lars Frykberg. Tel: +46186732 99. Fax: +4618673392.

e-mail: lars.frykberg@mikrob.slu.se

Department of

Microbiology, Swedish

University of Agricultural

Sciences, Box 7025,

S-750 07 Uppsala, Sweden

\begin{abstract}
Most strains of Staphylococcus aureus express IgG-binding activity and this binding has been considered to be solely mediated by protein A. However, the existence of a second gene in S. aureus strain 8325-4 encoding an IgG-binding polypeptide was recently reported. This novel IgG-binding polypeptide was found after panning a shotgun phage display library, made from chromosomal DNA, against immobilized human IgG. The complete gene (sbi) encoding this novel IgG-binding protein, denoted protein Sbi, has now been cloned and sequenced. Analysis of other $S$. aureus strains showed that this gene is not unique for strain 8325-4. The protein consists of $\mathbf{4 3 6}$ amino acids and exhibits an immunoglobulin-binding specificity similar to protein $A$. Furthermore, it is shown that Sbi is highly expressed in strain Newman 4, which shows that IgGbinding activity in S. aureus can be mediated by proteins other than protein A.
\end{abstract}

Keywords: Staphylococcus aureus, IgG-binding protein, Sbi and phage display

\section{INTRODUCTION}

Staphylococcus aureus is a pathogen responsible for a wide variety of diseases in humans and animals, including endocarditis, osteomyelitis, wound sepsis and mastitis (Easmon \& Adlam, 1983). The bacterium produces several potential virulence factors such as alpha-, beta-, gamma- and delta-toxins, toxic shock syndrome toxin, enterotoxins, leucocidin, proteases, coagulase and clumping factor (Iandolo, 1989). It is generally accepted that adhesion to tissues is required for bacterial colonization to occur. For this purpose, staphylococci express surface adhesins which interact with host matrix proteins such as fibronectin, vitronectin, collagen, laminin and bone sialoprotein (Patti et al., 1994). In addition, staphylococci are able to bind several serum proteins, such as $\operatorname{IgG}$, fibronectin, fibrinogen and thrombospondin, possibly masking the bacteria from the immune system of the host (Patti et al., 1994). However, the contribution and importance of each of these binding functions in different infections is still unclear.

The most studied receptor in S. aureus is protein A, a cell-wall-associated protein which binds to the Fc and

\section{Abbreviation: HRP, horseradish peroxidase.}

The GenBank accession number for the sequence reported in this paper is AF027155. the Fab regions of IgG from several species. Protein A in strain 8325-4 consists of five consecutive highly homologous domains, all with IgG-binding activity, followed by a region anchoring the protein in the cell wall (Forsgren \& Sjöquist, 1966; Löfdahl et al., 1983; Moks et al., 1986; Uhlén et al., 1984). IgG-binding ability is common among clinical strains of $S$. aureus (Forsgren \& Forsum, 1970; Forsgren et al., 1971), suggesting an important function in pathogenesis. The IgG-binding capacity has been thought to be mediated by protein A only. However, we recently identified a nucleotide sequence in $S$. aureus strain 8325-4 encoding a polypeptide, clearly distinguishable from protein $\mathrm{A}$, which binds IgG in a non-immune fashion (Jacobsson \& Frykberg, 1995). We now report on cloning and nucleotide sequence determination of the gene encoding this novel IgG-binding protein. The gene encodes a protein of 436 amino acids with one functional IgG-binding domain and without the typical Gram-positive cell wall anchoring sequence LPXTG (Schneewind et al., 1992, 1995; Navarre \& Schneewind, 1994), suggesting that the protein is not anchored in the cell wall. This gene is present in all tested strains of $S$. aureus.

\section{METHODS}

Bacterial strains, growth conditions, vectors and helper phage. The bacterial strains used are listed in Table 1. Phage $\mathrm{R} 408$ (Promega) was used as the helper phage for production 
Table 1. Bacterial strains

\begin{tabular}{|c|c|c|c|}
\hline Species & Strain & Characteristics and use & Reference \\
\hline \multirow[t]{2}{*}{ E. coli } & TG1 & $\begin{array}{l}\mathrm{F}^{+} \text {and amber suppressing; used for } \\
\text { construction of the phage library and } \\
\text { production of phage stocks }\end{array}$ & Sambrook et al. (1989) \\
\hline & MC1061 & Used for all other DNA manipulations & Wertman et al. (1986) \\
\hline \multirow[t]{4}{*}{ S. aureus } & $8325-4$ & NCTC 8325 cured from prophages & Novick (1967) \\
\hline & Wood 46 & Protein-A-negative reference strain & Kronvall et al. (1970) \\
\hline & Newman 4 & $\begin{array}{l}\text { Spontaneous mutant of strain Newman } \\
\text { with enhanced production of fibronectin- } \\
\text { binding protein }\end{array}$ & Jönsson et al. (1991) \\
\hline & Cowan I & $\begin{array}{l}\text { NCTC } 8350 \text {, high level producer of cell- } \\
\text { wall-bound protein A }\end{array}$ & Forsgren et al. (1971) \\
\hline S. epidermidis & 247 & & Rosendorf \& Kayser (1974) \\
\hline
\end{tabular}

Table 2. Oligonucleotides

\begin{tabular}{|c|c|c|}
\hline Name & Use & Sequence \\
\hline $\mathrm{Pe}$ & Sequencing of pHEN1 clones & 5'-TTG CCT ACG GCA GCC GCT GAA-3' \\
\hline My & Sequencing of pHEN 1 clones & 5'-TGC GGC CCC ATT CAG ATC CTC-3' \\
\hline Olg1 & Sequencing of $s b i$ & 5'-CTC CAT ATA GTA CTT CCT TA-3' \\
\hline Olg2 & Sequencing of $s b i$ & $5^{\prime}-$ GAG ATT GCA TCA TTT GCT GA-3' \\
\hline Olg3 & Sequencing of $s b i$ & 5'-GTA ACC ATA GTT AAA TGA AT-3' \\
\hline Olg4 & Sequencing of $s b i$ & $5^{\prime}$-CGA TAA ATC AGC AGC ATA TG-3' \\
\hline Olg5 & Sequencing of $s b i$ & 5'-CAA TCA CCA CAA ATT GAA AA-3' \\
\hline Olg6 & Sequencing of $s b i$ & 5'-TGG TGC T'TG TAG TGG AAA AG-3' \\
\hline Olg 8 & PCR for MAL-Sbi fusions & $\begin{array}{l}\text { 5'-AGT GGA TCC ACG CAA CAA ACT TCA } \\
\text { ACT AAG CA-3' }\end{array}$ \\
\hline Olg9 & $\begin{array}{l}\text { PCR for MAL-Sbi fusions and } \\
\text { construction of } s b i \text { probe }\end{array}$ & $\begin{array}{l}\text { 5'-AAT GTC GAC AAA CTA GAG AAG ATA } \\
\text { TTT TTG A-3' }\end{array}$ \\
\hline Olg10 & $\begin{array}{l}\text { PCR for MAL-Sbi fusions and } \\
\text { construction of } s b i \text { probe }\end{array}$ & $\begin{array}{l}5^{\prime} \text {-TAG GAT CCG TAC AAT CTT CTA AAG } \\
\text { CTA AAG A-3' }\end{array}$ \\
\hline
\end{tabular}

of phage stocks. Escherichia coli containing the pUC18 or pMAL-c2 vectors (New England Biolabs) was selected on LA plates [Luria-Bertani (LB) broth with $1.5 \%$ agar and $50 \mu \mathrm{g}$ ampicillin $\mathrm{ml}^{-1}$ ] and grown in LB broth supplied with $50 \mu \mathrm{g}$ ampicillin $\mathrm{ml}^{-1}$. E. coli containing the phagemid vector pHEN1 (Hoogenboom et al., 1991) was grown in the same medium supplemented with $1 \%(\mathrm{w} / \mathrm{v})$ glucose. Staphylococcal strains were grown in Tryptone Soya Broth (Oxoid). Staphylococcus epidermidis containing pRB473 (shuttle vector kindly provided by R. Brückner, Tübingen, Germany) constructs was grown in the same medium containing $20 \mu \mathrm{g}$ chloramphenicol $\mathrm{ml}^{-1}$.

Cloning and DNA sequencing. Restriction and modification enzymes were purchased from Promega, Amersham International or Boehringer Mannheim. Oligonucleotides were synthesized by Scandinavian Gene Synthesis or Pharmacia Biotech and are listed in Table 2.

All DNA manipulations were performed using standard methods (Sambrook et al., 1989), except ligations and smallscale plasmid preparations, for which the Ready to Go ligation kit (Pharmacia Biotech) and Wizard Minipreps DNA Purification Systems (Promega), respectively, were used according to the manufacturers' instructions. Plasmids were introduced into $E$. coli and staphylococci by electrotransformation (Oskouin \& Stewart, 1990). Staphylococcal chromosomal DNA was prepared according to Lindberg et al. (1972).

DNA was sequenced according to the dideoxy chain-termination method using the Sequenase version 2.0 DNA Sequencing kit from United States Biochemical. Restriction sites shown in Fig. 1 were used for construction of subclones used in determination of the nucleotide sequence. One additional clone, pHSBB7, was made (not shown) by Bal31 exonuclease digestion from the unique HindIII site in the $5^{\prime}$ direction of the gene, and sequenced. Different oligonucleotides were used as primers for determining the sequence of both DNA strands (Table 2). The PC/GENE program (IntelliGenetics) was used for the handling of the sequences. The EMBL, GenBank, SWISS-PROT and PIR databases were searched for sequence homologies.

To express the Sbi protein, two constructs were made in the pMAL-c2 vector. Primers Olg8 and Olg9 were used to PCRamplify the DNA encoding full-length protein lacking the signal sequence (aa 33-436). Primers Olg9 and Olg10 were used to PCR-amplify the DNA encoding a truncated version 
(aa 143-436) lacking also the IgG-binding domain. The obtained PCR products were digested with the restriction enzymes BamHI and Sall and ligated into the vector cleaved with the same enzymes and transformed into $E$. coli.

Southern blots and hybridizations were performed according to Sambrook et al. (1989), using a NcoI-Xbol fragment, i.e. the complete insert from clone Ig4 (Jacobsson \& Frykberg, 1995) ${ }^{32} \mathrm{P}$-labelled by random priming for detection and cloning of the $s b i$ gene. For detection of the $s b i$ gene in different $S$. aureus strains, the PCR fragment obtained by using $\mathrm{O} \lg 9$ and $\mathrm{Olg} 10$ (see above) was ${ }^{32} \mathrm{P}$-labelled by random priming. The hybridization was carried out at $50^{\circ} \mathrm{C}$ and the washing at $65^{\circ} \mathrm{C}$ in $0.1 \times \mathrm{SSC}(20 \times \mathrm{SSC}=3.0 \mathrm{M} \mathrm{NaCl}$ and $0.3 \mathrm{M}$ sodium citrate) and $0.1 \%$ SDS.

Shotgun mapping by phage display. The library was constructed from the cloned sbi gene essentially as described by Jacobsson \& Frykberg (1995). In short, the DNA from clone pPX1 (Fig. 1a) was sonicated and DNA fragments of approximately $50-300 \mathrm{bp}$ were isolated by preparative gel electrophoresis. The fragments were blunt-ended with T4 DNA polymerase and ligated into the phagemid pHEN1, previously digested with PstI, blunt-ended, and dephosphorylated with calf intestine alkaline phosphatase. The ligation was made using $1 \mu \mathrm{g}$ vector and $1 \mu \mathrm{g}$ DNA fragments and the mixture was transformed into $E$. coli TG1. The transformants were grown overnight in LB supplied with $50 \mu \mathrm{g}$ ampicillin $\mathrm{ml}^{-1}$ and $1 \%(\mathrm{w} / \mathrm{v})$ glucose and thereafter infected with helper phage R408 at an m.o.i. of 20 . After $1 \mathrm{~h}$, the culture was diluted and ampicillin was added to a final concentration of $50 \mu \mathrm{g} \mathrm{ml} \mathrm{m}^{-1}$. After $5 \mathrm{~h}$ growth at $37^{\circ} \mathrm{C}$, the bacteria were pelleted and the supernatant, containing the phages, was sterilely filtered.

The library was affinity-selected against human IgG (Kabivitrum) and positive clones were identified using labelled IgG as described by Jacobsson \& Frykberg (1995).

Determination of the specificities of Sbi and protein A. To determine the specificity of $\mathrm{Sbi}$, a phage stock was prepared as described above from clone Ig4, encoding the IgG-binding domain of Sbi (Jacobsson \& Frykberg, 1995). The stock was diluted to $10^{8}$ phagemid particles $\mathrm{ml}^{-1}$ and $100 \mu \mathrm{l}$ was panned as described by Jacobsson \& Frykberg (1995) against human $\operatorname{IgG}, \operatorname{Ig} M, \operatorname{IgA}, \operatorname{IgG} 3 \kappa$ and $\operatorname{IgG} 3 \lambda$ as well as $\operatorname{IgG}$ from rat, goat, pig, cow, sheep, horse, guinea pig, dog, rabbit and chicken (Sigma), immobilized in microwells at a concentration of $50 \mu \mathrm{g}^{-1}$. BSA was included as a negative control. The number of bound phagemid particles was determined as c.f.u. after infection of E. coli TG1 cells with the phage eluted at $\mathrm{pH}$ 2.

Protein purification and electrophoresis. The MAL fusion proteins MAL-Sbi (aa 33-346) and MAL-Sbis (aa 143-346) were purified from $E$. coli lysates on an amylose resin according to the manufacturer's instructions (New England Biolabs). MAL-Sbi was further purified on IgG-Sepharose according to the manufacturer's instructions (Pharmacia Biotech).

Antibodies against Sbi, developed in chickens, were obtained through Immunsystem (four immunizations of $50 \mu \mathrm{g}$ MAL$\mathrm{Sbi} \Delta$ protein). The antibodies were affinity-purified on immobilized MAL-Sbis protein and labelled with horseradish peroxidase (HRP; Boehringer Mannheim). Commercially available HRP-labelled chicken antibodies against protein A were obtained from Immunsystem.

The bacterial cells from overnight cultures of Newman 4
( $2 \mathrm{ml})$, Cowan I ( $2 \mathrm{ml})$ and S. epidermidis containing pShPX1 $(40 \mathrm{ml})$ were collected by centrifugation and washed once in PBS-D (140 mM NaCl, $8 \mathrm{mM} \mathrm{Na}{ }_{2} \mathrm{HPO}_{4}, 1.7 \mathrm{mM} \mathrm{KH} \mathrm{HO}_{4}$, $2.7 \mathrm{mM} \mathrm{KCl} ; \mathrm{pH} 7 \cdot 4$ ). Newman 4 and $S$. epidermidis cells were resuspended in $40 \mu \mathrm{lBS}$, followed by addition of $40 \mu \mathrm{l}$ $2 \times$ sample buffer $(1 \times$ buffer $=62.5 \mathrm{mM}$ Tris $/ \mathrm{HCl}, \mathrm{pH} 6.8$, $10 \%$ glycerol, $5 \%, \mathrm{v} / \mathrm{v}, \beta$-mercaptoethanol, $2 \%$ SDS and $0.01 \%$ bromophenol blue) and the samples were boiled for $2 \mathrm{~min}$. To release protein A, the same amount of cells in PBS was treated with lysostaphin $\left(0 \cdot 1 \mathrm{mg} \mathrm{m}^{-1}\right.$; Sigma) for $5 \mathrm{~min}$ at $37^{\circ} \mathrm{C}$ before addition of the sample buffer and boiling for $2 \mathrm{~min}$. Samples $(1 \mu \mathrm{l})$ were analysed by SDS-PAGE using the Phast system (Pharmacia Biotech) with PhastGel Gradient 8-25 gels and PhastGel SDS Buffer Strips. Also included were $0.025 \mu \mathrm{g}$ protein A (Pharmacia Biotech), $0.05 \mu \mathrm{g}$ MAL-Sbi and $0.05 \mu \mathrm{g}$ MAL-Sbi $\Delta$. The proteins were blotted onto nitrocellulose filters (Schleicher \& Schuell) and proteins were detected using HRP-labelled affinity-purified rabbit antichicken (diluted 1/500; Sigma), anti-Sbi $\left(10 \mu \mathrm{g} \mathrm{ml}^{-1}\right)$ or antiprotein $\mathrm{A}\left(15 \mu \mathrm{g} \mathrm{ml}^{-1}\right)$ antibodies. Bound antibodies were detected using 4-chloro-1-naphthol (Serva).

\section{RESULTS}

\section{Cloning and sequencing of the sbi gene encoding an IgG-binding protein}

The original clone (Fig. 1b, clone Ig4) expressing an IgGbinding polypeptide was earlier isolated from a shotgun phage display library made from $S$. aureus strain 8325-4 (Jacobsson \& Frykberg, 1995). The insert from this clone was used as a probe for identification and subsequently for cloning of the complete gene from $S$. aureus strain 8325-4. Chromosomal DNA was digested with PstI and XbaI, and the DNA fragments were separated by agarose gel electrophoresis followed by blotting onto a nitrocellulose filter. Hybridization with the $\mathrm{NcoI}-\mathrm{X}$ hoI fragment, derived from $\mathrm{Ig} 4$, showed that the gene resided on a fragment of approximately $3 \mathrm{~kb}$ in size. DNA fragments of this size were purified by agarose gel electrophoresis and cloned into the pUC18 vector. One clone, pPX1, hybridizing with the probe was further characterized by restriction enzyme analysis. Fig. 1 schematically shows the $3 \mathrm{~kb}$ Pst I-XbaI DNA fragment containing the $s b i$ gene and the different restriction enzymes used for subcloning.

The nucleotide sequence (GenBank accession number AF027155) encodes a protein of 436 amino acids, including a typical signal peptide with a putative cleavage site after amino acid 29 . The gene has the normal features associated with a functional gene: putative promoter sequences, a ribosome-binding site and an inverted repeat located after the translation termination stop codon. Only a part of the encoded protein shows homology to protein $\mathrm{A}$, while the rest of the protein does not show any homology to any known protein. A proline-rich sequence, containing eight prolines repeated every fifth amino acid, starts at position 267. Such sequences are normally found within cellwall-spanning domains. However, in this case the proline-rich region is not followed by the cell-wallsorting LPXTG motif (Schneewind et al., 1992, 1995; Navarre \& Schneewind, 1994). 
(a)

Pstl HindIII SnaBI

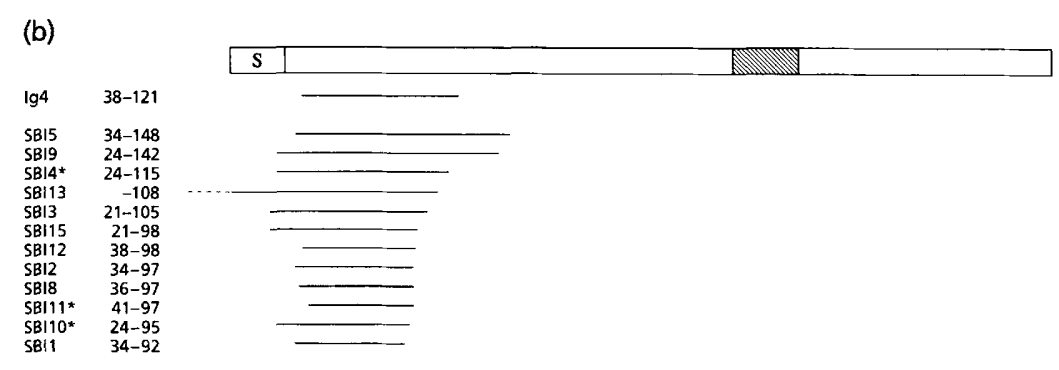

Fig. 1. (a) Cloned $3 \mathrm{~kb}$ Pstl-Xbal fragment from $S$. aureus strain $8325-4$ containing the sbi gene (clone pPX1). (b) Schematic drawing of Sbi aligned with the peptides encoded by the phagemid clones isolated by panning against IgG. Asterisks indicate that the clone was isolated several times independently. Ig4 represents the clone isolated previously (Jacobsson \& Frykberg, 1995). S denotes the signal sequence and the hatched bar represents a proline-rich region.

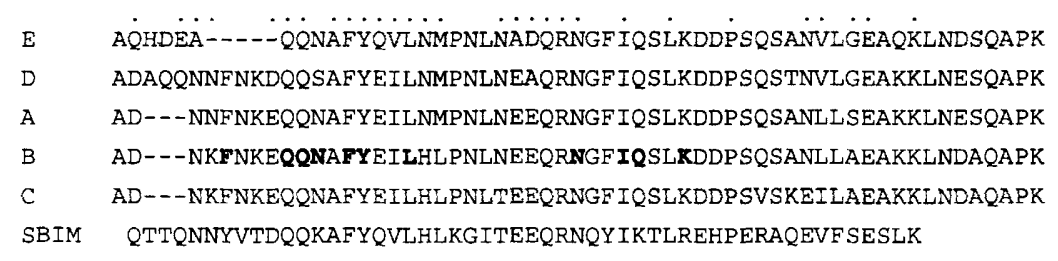

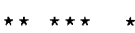

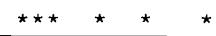
* *

\begin{abstract}
Fig. 2. Alignment of the deduced minimal IgG-binding domain of Sbi (SBIM; aa 41-92) with the repeated IgG-binding domains $A-E$ of staphylococcal protein A (Uhlén et al., 1984). Asterisks indicate amino acids present at the same position in all repeats of protein $A$ and in Sbi. Dots represent amino acids present in at least one of the repeats of protein $A$ and in Sbi. Shown in bold are residues in the $B$ domain of protein $A$ implicated in contributing to the contact with $\mathrm{C}_{\mathrm{H}} 2-\mathrm{C}_{\mathrm{H}} 3$ of the IgG molecule (Deisenhofer, 1981).
\end{abstract}

\section{Mapping of the IgG-binding domain in Sbi}

To determine the exact position of the IgG-binding domain in Sbi, a shotgun phage display library was made from clone $P P X 1$. After panning the library against immobilized human IgG, E. coli TG1 cells were infected with the eluted phage and the bacteria were spread on LA plates containing ampicillin. $\mathrm{Amp}^{\mathrm{R}}$ colonies were analysed for binding of HRP-labelled human IgG. Positive clones were isolated and the nucleotide sequences of the different inserts were determined. As seen in Fig. 1, all clones had inserts derived from the same part of $s b i$, suggesting that the encoded protein has only one functional IgG-binding domain. From the sequences of the binding clones in Fig. 1, the minimal IgG-binding domain is deduced to consist of 52 amino acids (SbiM; Fig. 2).

\section{Analysis of the immunoglobulin specificity of Sbi}

To analyse the immunoglobulin-binding properties of Sbi, clone Ig4 encoding the IgG-binding domain was used to produce phage particles displaying the binding domain on the surface. These phages were panned against different immunoglobulins and the number of binding phagemid particles was determined and used as a measure of the binding ability. As shown in Fig. 3, human, pig, rabbit and guinea pig IgG are bound most strongly.

\section{Analysis of the protein encoded by the sbi gene}

To further characterize the protein encoded by the $s b i$ gene, two clones were made in the pMAL-c2 vector, expressing the mature full-length protein (MAL-Sbi; aa 33-436) and a truncated protein (MAL-Sbi $\Delta$; aa 143-436) lacking the IgG-binding domain. The purified products were analysed by SDS-PAGE and Western blotting together with commercially available protein $\mathrm{A}$, cell-surface extract of $S$. epidermidis containing pShX1 and $S$. aureus Newman 4 , as well as lysed Newman 4 and Cowan I cells. Three duplicate gels were blotted onto nitrocellulose filters and the blots were developed with HRP-labelled rabbit IgG, HRP-labelled anti-protein A and HRP-labelled anti-Sbi, respectively (Fig. 4a-c). Fig. 4(a) shows that the MAL fusion of full-length protein Sbi and Sbi expressed in S. epidermidis bind $\operatorname{IgG}$, while MAL-Sbis, lacking the first 110 aa, does not bind IgG. IgG-binding activity is also detected in Newman 4 and Cowan I. As shown in Fig. 4(b), commercially available anti-protein $\mathrm{A}$ antibodies developed in chickens react with full-length Sbi (lanes 1 and 4) but not the MAL fusion lacking the IgG-binding domain (lane 2). Thus, they can not be used for discrimination between expression of protein A and Sbi. Fig. 4(c) shows that the antibodies against Sbi lacking the IgG-binding domain do not cross-react with protein $\mathrm{A}$ and are specific for Sbi. Accordingly, in strain Newman 4 high levels of Sbi are expressed while in Cowan I only protein A is detected. 


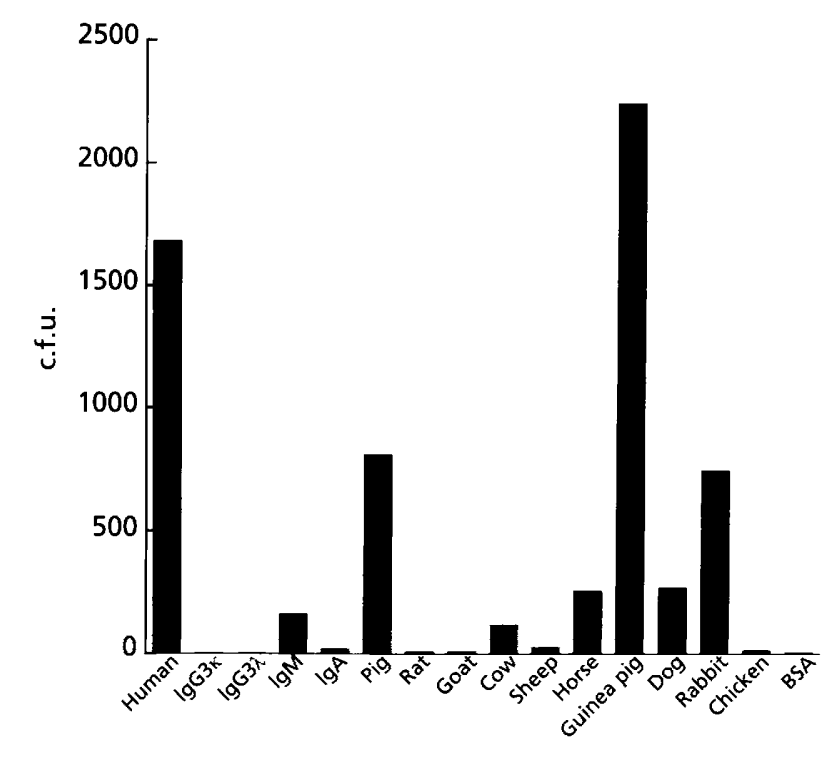

Fig. 3. Analysis of the specificity of the binding domain of Sbi (clone $\lg 4$ ) for various $\operatorname{lgGs}$ and human $\lg G 3 \kappa, \lg G 3 \lambda$, IgM and IgA. Each column represents a mean value of two independent experiments with the same phage stock. The $y$-axis shows the number of c.f.u. in $50 \mu$ l of the eluate.

\section{Occurrence of the sbi gene in staphylococcal strains}

Chromosomal DNA was isolated from $S$. aureus strains 8325-4, Cowan I, Newman 4 and Wood 46. The DNAs were digested with HindIII followed by agarose gel electrophoresis and then blotted onto a nitrocellulose filter. The sbi gene was detected in all four $S$. aureus strains tested (Fig. 5).

\section{DISCUSSION}

Analysis of IgG-binding activity in S. aureus by Western blotting usually reveals more than one protein band that interacts with IgG, and it has been assumed that these polypeptides represent breakdown products of protein A. As shown in this study, a second IgG-binding protein, $\mathrm{Sbi}$, is expressed in $S$, aureus. However, it is not surprising that Sbi has escaped detection as analysis of the expression of Sbi in $S$. aureus has been hampered by the ability of protein A to interact with IgGs from most mammalian species. Furthermore, both proteins migrate similarly in SDS-PAGE and have the same specificity for all tested immunoglobulins. As shown in Fig. 4(b), the commercially available anti-protein $\mathrm{A}$ antibodies crossreact with full-length Sbi but not with MAL-Sbi $\Delta$ (lacking the IgG-binding domain). It is likely that the cross-reaction is not unique to this source of antibodies and may have contributed to the failure to identify Sbi. Now the antibodies directed against Sbi produced in chickens allow discrimination between the expression of protein $\mathrm{A}$ and Sbi.

We have cloned and sequenced the sbi gene from $S$. aureus strain 8325-4. The detection of Sbi, expressed

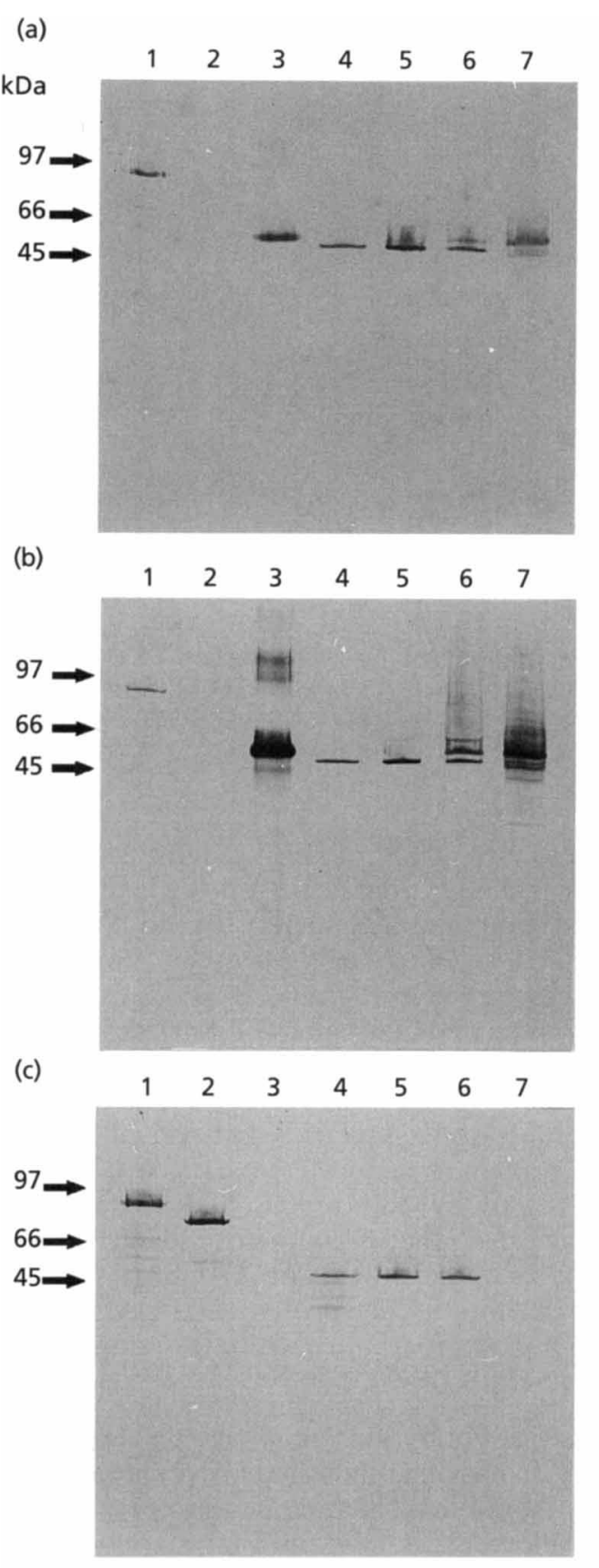

Fig. 4. Western blots, as described in Methods, detected with (a) affinity-purified rabbit anti-chicken antibodies, (b) antiprotein $A$ and (c) anti-Sbi. Lanes: 1, MAL-Sbi; 2, MAL-Sbi $\Delta ; 3$, protein $A ; 4$, Sbi expressed in $S$. epidermidis; 5 , $S$. aureus strain Newman 4 (boiled); 6, S. aureus Newman 4 (lysostaphin); 7,5 . aureus Cowan I (lysostaphin). Size markers are indicated on the left.

from its own promoter in S. epidermidis and as a MAL fusion in E. coli with HRP-labelled IgG, proves that this gene encodes a second IgG-binding protein. This protein consists of 436 amino acids and contains a signal sequence but lacks the cell-wall-sorting LPXTG motif, suggesting that the protein is not anchored in the cell wall. However, in strain Newman 4, which produces 


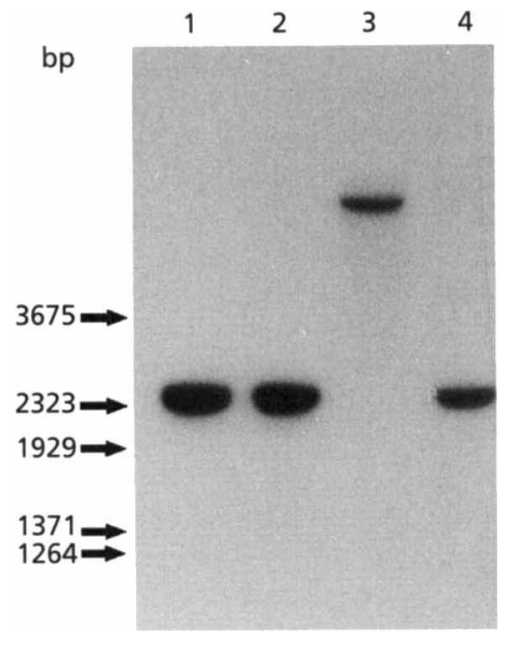

Fig. 5. Southern blot for the detection of the sbi gene in $S$. aureus strains. Lanes: 1 , strain $8325-4 ; 2$, Cowan I; 3, Newman $4 ; 4$, Wood 46 . Size markers are indicated on the left.

high amounts of Sbi, no Sbi is detected in the culture growth medium (data not shown). Instead, Sbi is released from the cell surface by addition of sample buffer (Fig. 4). In contrast, release of protein A requires treatment with lysostaphin (Fig. 4). This indicates that Sbi is associated with the cell surface by a different mechanism. The predicted $\mathrm{pK}$ a of mature Sbi is $9 \cdot 8$, which makes the protein positively charged at a neutral $\mathrm{pH}$. Perhaps the association between the bacteria and the Sbi protein is partly electrostatic since the protein is also released by addition of SDS (data not shown). There are also other examples of cell-surface-associated proteins that lack the LPXTG motif, such as the $S$. aureus elastin-binding protein (Park et al., 1996) and major histocompatibility complex class II analogue (Jönsson et al., 1995).

Mapping of Sbi by shotgun phage display suggests that the protein has one functional IgG-binding domain with a deduced minimal binding domain of 52 amino acids. Furthermore, expression and analysis of $\mathrm{NH}_{2}$-terminally truncated Sbi consisting of aa 143-436 show that no IgG-binding activity is located in this part of the protein (Fig. 4). The IgG-binding domain shows significant homology to the IgG-binding repeats of protein A (Fig. 2). Interestingly, the highest homologies are found in the regions involved in the binding of the $\mathrm{B}$ domain of protein A to the Fc fragment of IgG (Deisenhofer, 1981). Of the 11 amino acids in the B domain involved in the binding of $\operatorname{IgG}$, seven are identical, one is conservatively changed and three are substituted in Sbi. Analysis of the deduced amino acid sequence suggests the presence of a second IgG-binding domain immediately downstream of SbiM. However, no clones expressing this region were recovered in the mapping experiment. Still, it cannot be excluded that this region constitutes a second IgG-binding domain or at least contributes to the IgGbinding activity of protein Sbi.
A phage stock made from the originally isolated clone Ig4 (aa 38-121) (Fig. 1b) was used in an analysis of the immunoglobulin species reactivity (Fig. 3). A comparison between data on the specificity of protein A (Boyle, 1990) and the results for clone Ig4 (Fig. 3) shows that the two proteins exhibit a very similar immunoglobulinbinding profile. In addition, a study using one or two binding domains from protein $\mathrm{A}$ [clones Ig7 (domain $\mathrm{C}$ ) and Ig1 (D-A) described by Jacobsson \& Frykberg, 1995] gave an immunoglobulin-binding profile similar to that of Ig4 (data not shown). The display of protein domain(s) on the phage surface offers a quick and sensitive method for analysing specific binding to other molecules.

It is interesting to note that there are regions of homology between gene $s b i$ and one of the $S$. aureus genes encoding a fibrinogen-binding protein $(f i b)$ (Bodén \& Flock, 1994). The homology is found in two regions: $5^{\prime}$ of the translational start codon, nucleotide positions $86-108(22 / 23 \mathrm{nt})$; and over the translational start codon, nucleotide positions 179-193 (15/15 nt). This might indicate a common regulation of the expression of these two genes. The homology between the genes $s p a$ and $s b i$ is limited to the domain(s) encoding IgG-binding activity and no homology is found within the promoter sequences, suggesting that the genes are regulated in different ways.

The ability to bind $\operatorname{IgG}$ is very common among staphylococci and streptococci, which implies that IgG binding is of importance in pathogenesis. However, mutants low in expression of protein A and mutants with an inactivated protein A gene are only slightly less virulent than the wild-type strains (Jonsson et al., 1985; Patel et al., 1987). The existence of a second gene encoding an IgG-binding protein in such mutants may explain the failure to show that IgG binding indeed is of importance in virulence. The results in Fig. 5 show that the $s b i$ gene is not unique to strain 8325-4. The fact that Sbi has not earlier been reported in protein-A-negative mutants suggests that the expression level in these strains is low, at least in bacteria grown in vitro. This is supported by the findings that high levels of Sbi were detected in strain Newman 4, whilst it was almost undetectable in strain 8325-4 (data not shown) and not at all detectable in strain Cowan I (Fig. 4c). Thus, a mutant lacking both genes encoding IgG-binding proteins will be required for settling the importance of $\operatorname{IgG}$ binding in the virulence of $S$. aureus.

\section{ACKNOWLEDGEMENTS}

We thank A. Larsson at Immunsystem $A B$ for fruitful discussions about the chicken antibodies and R. Brückner for providing the shuttle vector pRB473. This investigation was supported by grants from the Swedish Medical Research Council (B 95-16X-03778-24B), the Swedish Research Council for Engineering Sciences (94-380), the Immunotechnology program founded by the Swedish National Board for Industrial and Technical Development (P2355-1) and the Pharmacia Research Fund. 


\section{REFERENCES}

Bodén, M. K. \& Flock, J.-I. (1994). Cloning and characterization of a gene for a $19 \mathrm{kDa}$ fibrinogen-binding protein from Staphylococcus aureus. Mol Microbiol 12, 599-606.

Boyle, M. D. P. (1990). Bacterial Immunoglobulin-binding Proteins, vols 1 and 2. London: Academic Press.

Deisenhofer, J. (1981). Crystallographic refinement and atomic models of human $\mathrm{Fc}_{\mathrm{c}}$ fragment and its complex with fragment B of protein A from Staphylococcus aureus at 2.9- and 2.8- $\AA$ resolution. Biochemistry 20, 2361-2370.

Easmon, C. S. F. \& Adlam, C. (1983). Staphylococci and Staphylococcal Infections, vols 1 and 2. London: Academic Press.

Forsgren, A. \& Forsum, U. (1970). Role of protein A in non-specific immunofluorescence of Staphylococcus aureus. Infect Immun 2, 387-391.

Forsgren, A. \& Sjöquist, J. (1966). 'Protein A' from S. aureus. I. Pseudoimmune reaction with human $\gamma$-globulin. J Immunol 97, 822-827.

Forsgren, A., Nordström, K., Philipson, L. \& Sjöquist, J. (1971). Protein A mutants of Staphylococcus aureus. J Bacteriol 107, 245-250.

Hoogenboom, H. R., Griffiths, A. D., Johnson, K. S., Chiswell, D. J., Hudson, P. \& Winter, G. (1991). Multi-subunit proteins on the surface of filamentous phage: methodologies for displaying antibody (Fab) heavy and light chains. Nucleic Acids Res 19, 4133-4137.

landolo, J. J. (1989). Genetic analysis of extracellular toxins of Staphylococcus aureus. Annu Rev Microbiol 43, 375-402.

Jacobsson, K. \& Frykberg, L. (1995). Cloning of ligand-binding domains of bacterial receptors by phage display. BioTechniques 18, 878-885.

Jönsson, K., Signäs, C., Müller, H.-P. \& Lindberg, M. (1991). Two different genes encode fibronectin binding proteins in Staphylococcus aureus. The complete sequence and characterization of the second gene. Eur J Biochem 202, 1041-1048.

Jönsson, K., McDevitt, D., Homonylo McGavin, M., Patti, J. M. \& Höök, M. (1995). Staphylococcus aureus expresses a major histocompatibility complex class II analog. J Biol Chem 270, 21457-21460.

Jonsson, P., Lindberg, M., Haraldsson, I. \& Wadström, T. (1985). Virulence of Staphylococcus aureus in a mouse mastitis model: studies of alpha hemolysin, coagulase, and protein $\mathrm{A}$ as possible virulence determinants with protoplast fusion and gene cloning. Infect Immun 49, 765-769.

Kronvall, G., Quie, P. G. \& Williams, R. C., Jr (1970). Quantification of staphylococcal protein A: determination of equilibrium constant and number of protein A residues on bacteria. JImmunol 104, 140-147.

Lindberg, M., Sjöström, J.-E. \& Johansson, T. (1972). Trans- formation of chromosomal and plasmid characters in Staphylococcus aureus. J Bacteriol 109, 844-847.

Löfdahl, S., Guss, B., Uhlén, M., Philipson, L. \& Lindberg, M. (1983). Gene for staphylococcal protein A. Proc Natl Acad Sci USA 80, 697-701.

Moks, T., Abrahmsén, L., Nilsson, B., Hellman, U., Sjöquist, J. \& Uhlén, M. (1986). Staphylococcal protein A consists of five IgGbinding domains. Eur J Biochem 156, 637-643.

Navarre, W. W. \& Schneewind, O. (1994). Proteolytic cleavage and cell wall anchoring at the LPXTG motif of surface proteins in Gram-positive bacteria. Mol Microbiol 14, 115-121.

Novick, R. P. (1967). Properties of a cryptic high-frequency transducing phage in Staphylococcus aureus. Virology 33, 155-156.

Oskouin, B. \& Stewart, G. C. (1990). Repression and catabolite repression of lactose operon of S. aureus. J Bacteriol 172, 3804-3812.

Park, P. W., Rosenbloom, J., Abrams, W. R., Rosenbloom, J. \& Mecham, R. P. (1996). Molecular cloning and expression of the gene for elastin-binding protein (ebpS) in Stapbylococcus aureus. J Biol Chem 271, 15803-15809.

Patel, A. H., Nowland, P., Weavers, E. D. \& Foster, T. (1987). Virulence of protein A and alpha-toxin-deficient mutants of Staphylococcus aureus isolated by allele replacement. Infect Immun 55, 3103-3110.

Patti, J. M., Allen, B. L., McGavin, M. J. \& Höök, M. (1994). MSCRAMM-mediated adherence of microorganisms to host tissue. Annu Rev Microbiol 48, 585-617.

Rosendorf, L. L. \& Kayser, F. H. (1974). Transduction and plasmid deoxyribonucleic acid in a multiply antibiotic-resistant strain of Staphylococcus epidermidis. J Bacteriol 120, 679-686.

Sambrook, J., Fritsch, E. F. \& Maniatis, T. (1989). Molecular Cloning: a Laboratory Manual, 2nd edn. Cold Spring Harbor, NY: Cold Spring Harbor Laboratory.

Schneewind, O., Model, P. \& Fischetti, V. A. (1992). Sorting of protein A to the staphylococcal cell wall. Cell 70, 267-281.

Schneewind, O., Fowler, A. \& Faull, K. F. (1995). Structure of cell wall anchor of surface proteins in Staphylococcus aureus. Science 268, 103-106.

Uhlén, M., Guss, B., Nilsson, B., Gatenbeck, S., Philipson, L. \& Lindberg, M. (1984). Complete sequence of the staphylococcal gene encoding protein $\mathrm{A}$, a gene evolved through multiple duplications. J Biol Chem 259, 1695-1702.

Wertman, K. F., Wyman, A. R. \& Botstein, B. (1986). Host/vector interactions which affect the viability of recombinant phage lambda clones. Gene 49, 253-262.

Received 29 September 1997; revised 26 November 1997; accepted 22 December 1997. 